\title{
Interaction between seed detectability and seed preference affects harvest rates of granivorous rodents
}

\author{
William S. LONGLAND ${ }^{1}$ AND Lindsay A. Dimitri ${ }^{1, *}$ \\ ${ }^{1}$ USDA, Agricultural Research Service, Great Basin Rangeland Research Unit, 920 Valley Rd., Reno, NV 89512
}

\begin{abstract}
Granivorous rodents commonly exhibit preferences for seeds of particular plant species. However, among buried seeds that are available, rodents may find that alternate, less desirable seeds are more easily located by olfaction than preferred seeds. Seeds of Indian ricegrass (Achnatherum hymenoides) are a highly preferred food resource for seed-caching desert heteromyid rodents. We tested relative abilities of heteromyids to locate buried caches of Indian ricegrass seeds versus seeds of another plant species (cheatgrass, Bromus tectorum) that are common in heteromyid diets at a western Nevada field site. Rodents located more cheatgrass than Indian ricegrass seed caches in the field when seeds were unaltered. When ground, however, detectability of preferred Indian ricegrass seeds increased, presumably due to release of volatile compounds inside seeds, and more ground Indian ricegrass seed caches were found and removed compared with ground cheatgrass caches. Grinding cheatgrass seeds did not affect harvest rates of cheatgrass caches. Results of a laboratory cache removal experiment using 2 heteromyid species, Merriam's kangaroo rats (Dipodomys merriami) and long-tailed pocket mice (Chaetodipus formosus), mirrored field cache removal results. Dispersal of Indian ricegrass seeds and establishment of new seedlings occurs largely through emergence of seedlings from heteromyid scatterhoard caches. Our results suggest that Indian ricegrass seeds may have been selected for reduced olfactory detectability to minimize the probability that they are recovered by rodents for later consumption once they have been cached.
\end{abstract}

RESUMEN._Los roedores granívoros suelen exhibir preferencias por semillas de especies vegetales particulares. Sin embargo, entre las semillas enterradas que están disponibles, los roedores pueden encontrar semillas menos deseables alternas para ser más fácilmente situado por olfacción que las semillas preferidas. Las semillas de Achnatherum hymenoides son un recurso alimenticio altamente preferido para los roedores heteromyid de desierto que almacenan semillas enterrándolas en el suelo. Hemos probado habilidades relativas de heteromyids para ubicar semillas almacenadas en el suelo de A. hymenoides contra las semillas de otra especie de la planta (cheatgrass, Bromus tectorum) que son comunes en las dietas de heteromyids en un sitio de campo occidental de Nevada. Los roedores localizaron más semillas de B. tectorum cuando se compara con semillas de A. hymenoides en el campo cuando las semillas no se molido (entero). Sin embargo, cuando se molturaron, los compuestos volátiles liberados de las semillas internas aumentaron la detectabilidad de las semillas de A. hymenoides preferidas, y roedores encontraron y retiraron más semillas A. hymenoides molido desde semillas A. hymenoides entero en comparación con las semillas enterrado de B. tectorum molido. Las semillas de B. tectorum molienda no afectaron las tasas de cosecha de semillas enterrado de B. tectorum. Los resultados de un experimento de eliminación de semillas enterradas de laboratorio utilizando dos especies de heteromyid, Dipodomys merriami y Chaetodipus formosus, fueron similares a los experimento de campo. La dispersión de semillas de A. hymenoides y el establecimiento de nuevas plántulas se produce en gran medida a través de la aparición de plántulas desde semillas enterradas por roedores. Se han seleccionado semillas de A. hymenoides para reducir la detectabilidad olfativa para minimizar la probabilidad de que sean recuperadas por roedores para consumo posterior una vez que han sido enterrados.

Granivorous rodents often exhibit distinct preferences for seeds of particular plant species, selecting among those that are available in their local environments (Hay and Fuller 1981, Kelrick et al. 1986, Lobo et al. 2009, Barga and Vander Wall 2013, Cao et al. 2016, Longland and Dimitri 2016). When a selection of various seed species is available on plants or on the soil surface, rodents can readily select preferred seeds. However, rodents must often locate seeds that are buried in the soil, and in such cases relative detectability of available seed types may preclude foraging granivores from searching for and finding preferred seed types (Hollander et al. 2012). Rodents detect buried seeds by olfaction (Howard and Cole 1967, Howard et al. 1968, Lockard and Lockard 1971), and the

*Corresponding author: lindsaydimitri@outlook.com 
release of volatile compounds from seeds determines their detectability (Jorgensen 2001, Vander Wall 2003, Paulsen et al. 2013). Rodents cache seeds for future consumption either in a central nest or burrow ("larderhoarding") or in numerous shallow, subsurface caches ("scatterhoards"). Individual animals can use spatial memory to relocate scatterhoards that they have made (Jacobs 1992), but other animals can only find them using olfaction. Plants that utilize scatterhoarding rodents as seed dispersers should therefore be under strong selection for impermeable seed coats that hide olfactory cues and thereby reduce the probability that scatterhoard caches will be detected and consumed by animals naïve to their locations (Vander Wall 2003, Hollander et al. 2012, Paulsen et al. 2013).

For approximately 20 years, we have studied interactions between desert rodents in the family Heteromyidae and the seeds they consume and cache at the Hot Springs Mountains in western Nevada (cf. Longland and Bateman 1998, Pyare and Longland 2000, Longland et al. 2001, Longland 2007, Longland and Ostoja 2013). Seedlings of 2 grass species, one a native perennial bunchgrass (Indian ricegrass, Achnatherum hymenoides) and the other an introduced annual (cheatgrass, Bromus tectorum), constitute the vast majority of seedlings that emerge in clusters from rodent scatterhoards at the site (Fig. 1a, lb). Seeds of both of these grasses (or of a congener of cheatgrass) have been documented in the diets of heteromyids at another Great Basin Desert site near the Hot Springs Mountains (McAdoo et al. 1983) and in a Mojave Desert study (Bradley and Mauer 1971).

Indian ricegrass seeds appear to be a highly preferred food resource of heteromyids. It was by far the most common seed in diets of Merriam's kangaroo rats (Dipodomys merriami) at a Mojave site (Bradley and Mauer 1971). At a Great Basin site, seeds of an introduced plant, the most common item in heteromyid diets throughout the majority of the year, dropped out of the diet and were replaced by Indian ricegrass seeds when the latter became available (McAdoo et al. 1983). In a field study of stomach contents of Ord's kangaroo rats (D. ordii), Henderson (1990) found Indian ricegrass seeds to be the most abundant food item during the time of year that the plant produces seeds. Another field study that used seed removal experiments to assess dietary preferences of granivores using 6 locally available seeds found Indian ricegrass to be one of 2 preferred seed types and cheatgrass to be one of the 2 lowest-ranked seeds (Kelrick et al. 1986). With the latter study being an exception, little is known about rodent-seed interactions involving cheatgrass. However, the invasive nature of this plant has made it common and often abundant, frequently even occurring as a monoculture, throughout much of the desert southwest, especially in the Great Basin. Cheatgrass has probably become an important food item for granivorous rodents as illustrated by the fact that it often emerges from scatterhoards made by heteromyids (Fig. 1b), and we have found it associated with heteromyid larderhoards as well (Fig. 1c).

Indian ricegrass seedling recruitment commonly occurs from germination of clustered seeds in scatterhoards made by heteromyid rodents (McAdoo et al. 1983, Longland et al. 2001). Although cheatgrass seeds are also cached by heteromyids and its seedlings commonly emerge from rodent scatterhoards, the competition that results from cheatgrass seedlings emerging in clusters negatively impacts its seedling survival, while Indian ricegrass seedlings can show enhanced survival as clump size increases (McMurray et al. 1997). Perhaps the failure to realize benefits from dispersal by these rodents is to be expected for cheatgrass. Cheatgrass is not native to North American deserts and thus lacks an evolutionary history with heteromyids. Moreover, granivory is uncommon among the rodent fauna in arid areas of the world other than North America (Mares 1993, Kelt et al. 1996, Fox 2011), so cheatgrass is unlikely to show adaptations associated with rodent granivory.

Potential benefits of seedling emergence from rodent scatterhoards for Indian ricegrass and the apparent desirability of its seeds as a food resource for rodents suggest that Indian ricegrass should be selected for minimizing olfactory detectability of its seeds. There is no reason to expect that cheatgrass seeds should be similarly adapted. Moreover, the husk of Indian ricegrass seeds completely surrounds and contains the embryo, where volatile compounds occur that could provide olfactory signals to foraging granivores, whereas mature 

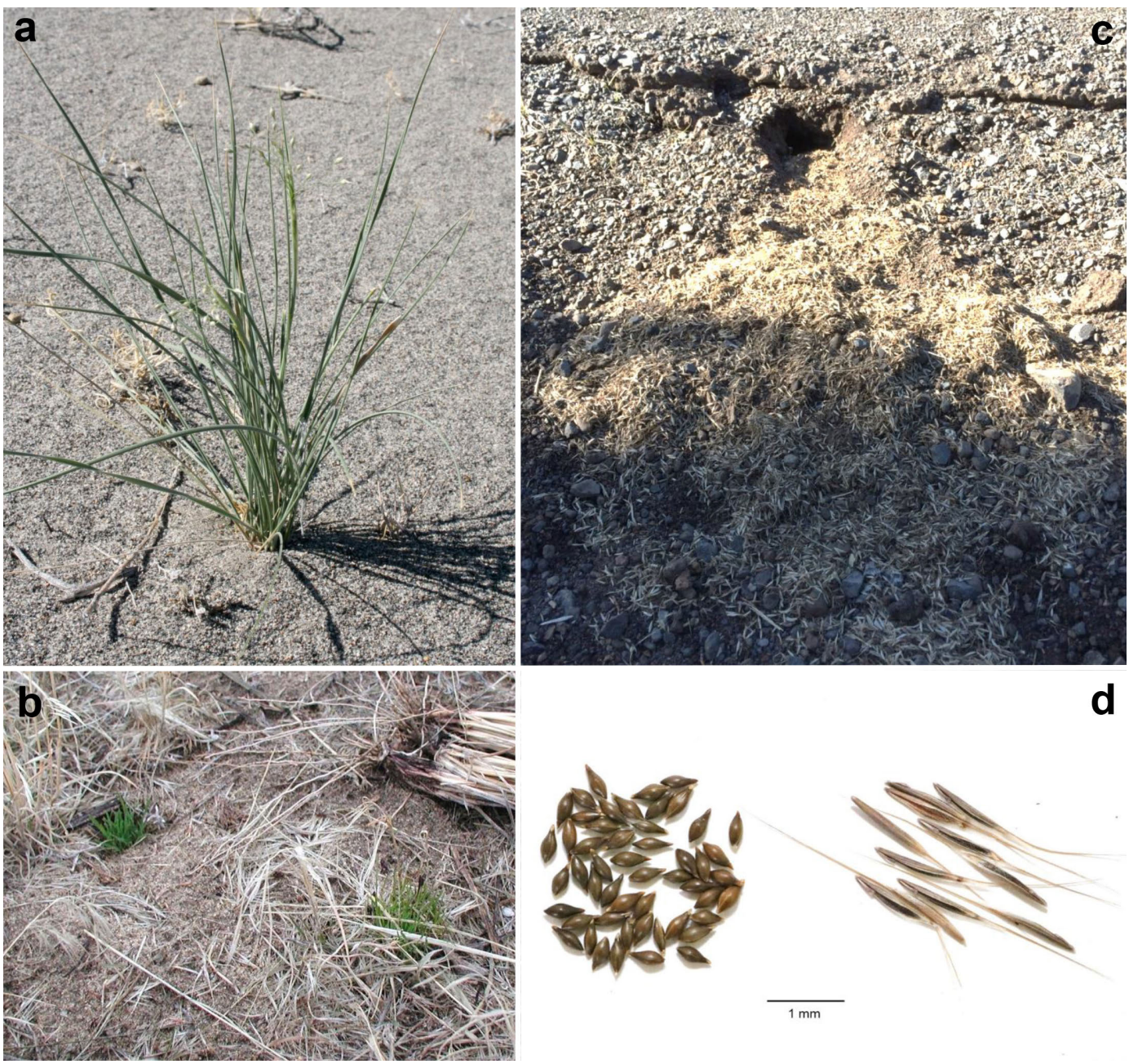

Fig. 1. (a) Clustered Indian ricegrass seedlings that established from a rodent seed cache. (b) Clustered cheatgrass seedlings that emerged from 2 rodent seed caches. (c) Burrow opening of a California kangaroo rat (Dipodomys californicus) with a large quantity of cheatgrass seeds spilling out the entrance. (d) Seeds of Indian ricegrass (left) and cheatgrass (right). Note the dark-colored embryos that are exposed on the cheatgrass seeds and the relatively impermeable seed coats that completely surround Indian ricegrass seeds.

cheatgrass seeds have a husk that splits and exposes a portion of the embryo (Fig. 1d). This should make cheatgrass easier for rodents to detect by olfaction, reducing search costs for this seed relative to Indian ricegrass seeds, which we presume are more desirable to rodents. These 2 seed types and granivorous heteromyid rodents thus present an ideal system to explore how detectability of, and preferences for, alternate food types may interact to determine the composition of animal diets. Therefore, we conducted both laboratory and field experiments to test the prediction that scatterhoards containing Indian ricegrass seeds are less detectable to heteromyid rodents naïve to their locations than scatterhoards of cheatgrass seeds and that rodents would therefore be able to locate more cheatgrass caches than Indian ricegrass caches despite the latter being preferred. We further predicted that if intact seeds of these 2 plant species were ground to expose compounds within the embryos to the environment, the resulting enhanced detectability would then allow rodents to locate more caches of preferred Indian ricegrass seeds. We prefaced 
these experiments with a simple laboratory choice test offering intact cheatgrass and Indian ricegrass seeds to captive heteromyid rodents to verify a preference of rodents for the latter seed type.

\section{Methods}

We used captive individuals of 2 heteromyid species in laboratory seed preference experiments, Merriam's kangaroo rats $(n=7$ individuals) and long-tailed pocket mice (Chaetodipus formosus; $n=13$ ). Animals were livetrapped at the Hot Springs Mountains and were housed individually under a 12-h light: 12-h dark daily cycle in plexiglass cages with a sand substrate and a small can for shelter and security; they were fed mixed birdseed, lettuce, and mealworms. For preference experiments, we tested animals individually in small terrariums with a thin layer of sand covering the bottom. Two petri dishes, one containing $3.0 \mathrm{~g}$ of Indian ricegrass seeds and one containing $3.0 \mathrm{~g}$ of cheatgrass seeds, were placed at one end of a terrarium. An animal was removed from its housing cage along with its security can, placed inside its can at the opposite end of the terrarium from the petri dishes at 17:00 on a given day, and removed the following morning at 08:00. Animals typically remained in their cans until bright overhead light was replaced by dim red light for the 12-h dark period (18:00-06:00) of each 15-h trial. Following trials, remaining seeds were emptied from each petri dish, sifted from the sand substrate in the entire terrarium, separated by seed type, and weighed.

We also conducted laboratory experiments to test rodents' abilities to locate buried caches of cheatgrass and Indian ricegrass seeds in an indoor foraging arena. Merriam's kangaroo rats $(n=8)$ and long-tailed pocket mice $(n=10)$ were again tested individually as in preference experiments. A square arena was constructed of plywood and was $2.4 \mathrm{~m}$ on each side and $1.2 \mathrm{~m}$ in height. One side of the arena had 2 holes separated by $1 \mathrm{~m}$ that each opened into small wooden nestboxes. The 2 nestboxes were connected to one another by a 7-cm diameter PVC tube, making a complex artificial burrow. The floor of the arena was covered by sieved sand to a depth of $\sim 5 \mathrm{~cm}$ for trials. To mimic natural rodent scatterhoards in each trial, we buried 5 caches each of whole Indian ricegrass seeds at random locations throughout the arena and did the same with 5 caches of whole cheatgrass seeds. We also ground seeds by pulsing them several times in a blender and placed 5 caches of each seed type of the resulting crushed seeds at random locations in the arena. Thus, there were 20 seed caches that could potentially be located during a trial. Although cache location coordinates were randomly generated, they were constrained to being $\geq 20 \mathrm{~cm}$ from arena walls to reduce the likelihood of chance encounters by animals patrolling the perimeter of the arena. Each cache was buried $1.0 \mathrm{~cm}$ deep and contained $0.5 \mathrm{~g}$ of seeds (or seed fragments for caches of crushed seeds). We placed a single animal along with its security can inside one of the nestboxes at 17:00 for each trial and removed it the following morning at 08:00, using the same light:dark cycle during a trial as in laboratory preference experiments. Following each trial, we searched the arena and determined the number of each type of seed cache that the rodent had found and excavated. These were easily identified by the presence of a small pit where the rodent had dug up a given cache, but we also sieved sand within a circle approximately $5 \mathrm{~cm}$ in radius around all cache locations to remove unexcavated caches and to determine whether each cache that rodents found during trials had been removed completely versus only partially harvested. We then sieved the sand in the entire arena to remove any cached seeds or seed fragments before conducting the next trial. Laboratory cache removal and seed preference experiments were conducted between October 2005 and June 2006. Individual animals were tested in a single trial of each experiment.

Field experiments testing abilities of heteromyids to locate buried cheatgrass and Indian ricegrass seeds were conducted outside a series of $5 \times 5-\mathrm{m}$ fenced plots that were described in previous studies at Hot Springs Mountains (see Longland et al. 2001, Longland 2007). Seed treatments included both whole and ground Indian ricegrass and cheatgrass seeds as in laboratory cache removal trials. For each trial, we buried 2 caches of each seed treatment around each of 12 fenced plots, yielding a total of 24 caches of each treatment per trial. At each of the 4 corners of a plot, one cache was placed $1 \mathrm{~m}$ from the 


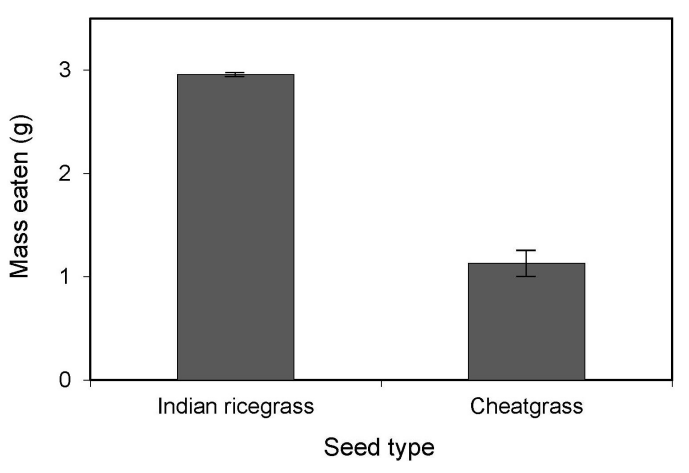

Fig. 2. Mean mass $( \pm \mathrm{SE})$ of Indian ricegrass seeds and cheatgrass seeds consumed by heteromyid rodents out of $3.0 \mathrm{~g}$ of each seed type available in laboratory seed preference trials.

corner post and a second was placed $2 \mathrm{~m}$ from the post with the angle of cache placement relative to the post being randomly generated (but constrained to the outside of fenced plots) to prevent rodents from learning patterns of cache placement. As in laboratory trials, caches contained $0.5 \mathrm{~g}$ of seeds and were buried $1.0 \mathrm{~cm}$ deep. Seed treatments were paired as follows, with a different pair cached at each corner of each plot: (1) whole Indian ricegrass (WI treatment) and whole cheatgrass (WC), (2) ground Indian ricegrass (GI) and ground cheatgrass (GC), (3) whole Indian ricegrass and ground Indian ricegrass, and (4) whole cheatgrass and ground cheatgrass. We allowed 3 nights before inspecting cache locations and recording cache removal by rodents, which was apparent due to pits where digging occurred. If very few caches had been removed we continued the trial for up to 4 additional nights until $>10 \%$ had been removed; this occurred in 6 of 20 total trials. We conducted trials during March through September from 2004 to 2007.

For laboratory seed preference experiments, we used trials of individual animals as replicates to test for differences in masses of each of the 2 seed types consumed using $t$-tests for paired comparisons (Proc TTEST, SAS 2012). Tests were conducted for each rodent species separately and for both species combined. Our interest in relative detectability of Indian ricegrass versus cheatgrass seeds is best addressed by contrasting the 4 pairs of seed treatments described above for the field cache removal experiment. Therefore, we analyzed field cache removal data by contrasting the following using $t$-tests for paired comparisons (Proc TTEST, SAS 2012) with trials as replicates: (1) number of WI versus WC caches removed, (2) GI versus GC, (3) WI versus GI, and (4) WC versus GC. For comparability to the field results, we also used the same 4 tests to analyze laboratory cache removal data, which was done separately for each of the 2 heteromyid species tested as well as for combined data. Finally, we used a contingency test to analyze effects of seed type (Indian ricegrass or cheatgrass) and seed condition (whole or ground) on numbers of laboratory trials in which at least some of the caches were removed completely versus numbers in which there was some partial cache removal (Proc CATMOD, SAS 2012).

\section{RESUlTS}

In the laboratory seed preference experiment, rodents consumed significantly more Indian ricegrass than cheatgrass seeds when data were combined for both rodent species tested $(t=19.30, \mathrm{df}=19, P<0.0001$; Fig. 2$)$ as well as when tested separately for Merriam's kangaroo rats $(t=10.18, \mathrm{df}=6, P<$ $0.0001)$ or for long-tailed pocket mice $(t=$ $18.30, \mathrm{df}=12, P<0.0001)$. All individuals of both species consumed a greater mass of Indian ricegrass than of cheatgrass seeds.

Rodents located and removed significantly fewer WI seed caches than WC caches in field experiments $(t=-2.10, \mathrm{df}=19, P=0.0493)$; in contrast, there was no difference in numbers of GI versus GC caches removed ( $t=$ 1.62 , df $=19, P=0.1227$; Fig. 3). Significantly fewer WI than GI caches were removed $(t=$ -3.75 , df $=19, P=0.0014)$, but numbers of WC and GC caches removed were similar $(t$ $=0.55, \mathrm{df}=19, P=0.5906$; Fig. 3).

Combining data for the 2 rodent species tested in the laboratory cache removal experiment, animals found and harvested significantly fewer WI caches than WC caches $(t=$ -2.75 , df $=17, P=0.0137$ ), but they harvested significantly more GI than GC caches $(t=4.12, \mathrm{df}=17, P=0.0007$; Fig. 4a). Animals also harvested significantly fewer WI than GI caches $(t=-6.42$, df $=17, P<$ 0.0001 ), but numbers of WC and GC caches harvested were statistically similar $(t=-0.26$, $\mathrm{df}=17, P=0.7978)$. Contingency test results 


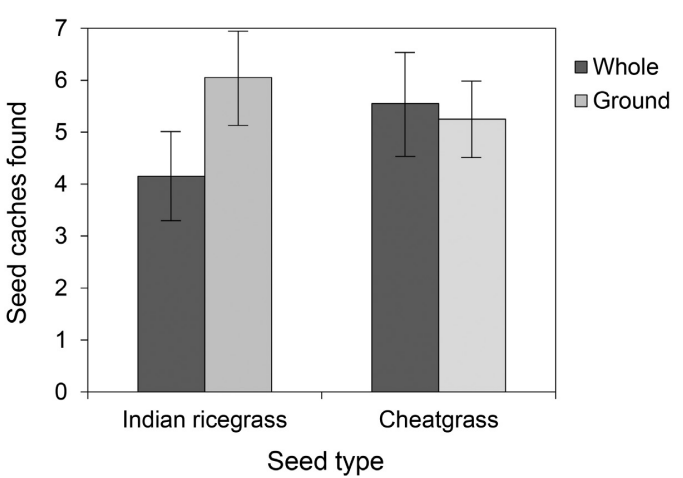

Fig. 3. Mean number of seed caches removed per trial $( \pm \mathrm{SE})$ of Indian ricegrass seeds and cheatgrass seeds at the Hot Springs Mountains, Nevada, for both whole and ground seeds.

indicated that seed type had a significant effect on numbers of trials in which caches were completely removed versus partially removed $\left(\chi^{2}=13.33, \mathrm{df}=1, P=0.0003\right)$, as a much greater proportion of trials had Indian ricegrass caches completely removed relative to cheatgrass (Table 1). Relative numbers of trials with complete versus partial cache removal did not differ between whole and ground seeds $\left(\chi^{2}=0.59, \mathrm{df}=1, P=0.4433\right)$ nor did seed condition interact significantly with seed type $\left(\chi^{2}=0.37\right.$, $\mathrm{df}=1, P=$ $0.5420)$. Although the direction of change for WI versus WC seeds was similar when data were analyzed for each species separately, these changes were nonsignificant for both long-tailed pocket mice $(t=-1.77, \mathrm{df}=9, P$ $=0.1114$; Fig. $4 \mathrm{~b}$ ) and Merriam's kangaroo rats $(t=-2.05, \mathrm{df}=7, P=0.0796$; Fig. $4 \mathrm{c})$. As in the combined analysis, both species removed significantly more GI than GC caches (pocket mice: $t=2.67, \mathrm{df}=9, P=0.0258$; kangaroo rats: $t=3.07, \mathrm{df}=7, P=0.0181)$ and significantly fewer WI than GI caches (pocket mice: $t=-4.61, \mathrm{df}=9, P=0.0013$; kangaroo rats: $t=-4.25, \mathrm{df}=7, P=0.0038)$, but neither species differed in numbers of WC versus GC caches removed (pocket mice: $t=-0.52 \mathrm{df}=$ $9, P=0.6164$; kangaroo rats: $t=0.19, \mathrm{df}=7$, $P=0.8565)$.

\section{Discussion}

The laboratory preference experiment provides convincing support for our assumption that heteromyid rodents prefer Indian a) Both species combined

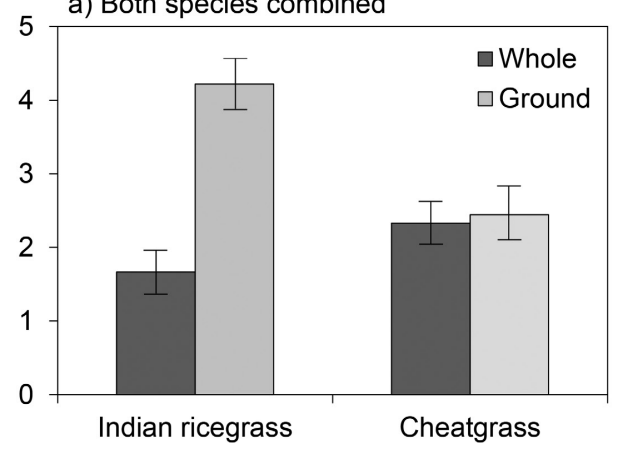

b) Chaetodipus formosus
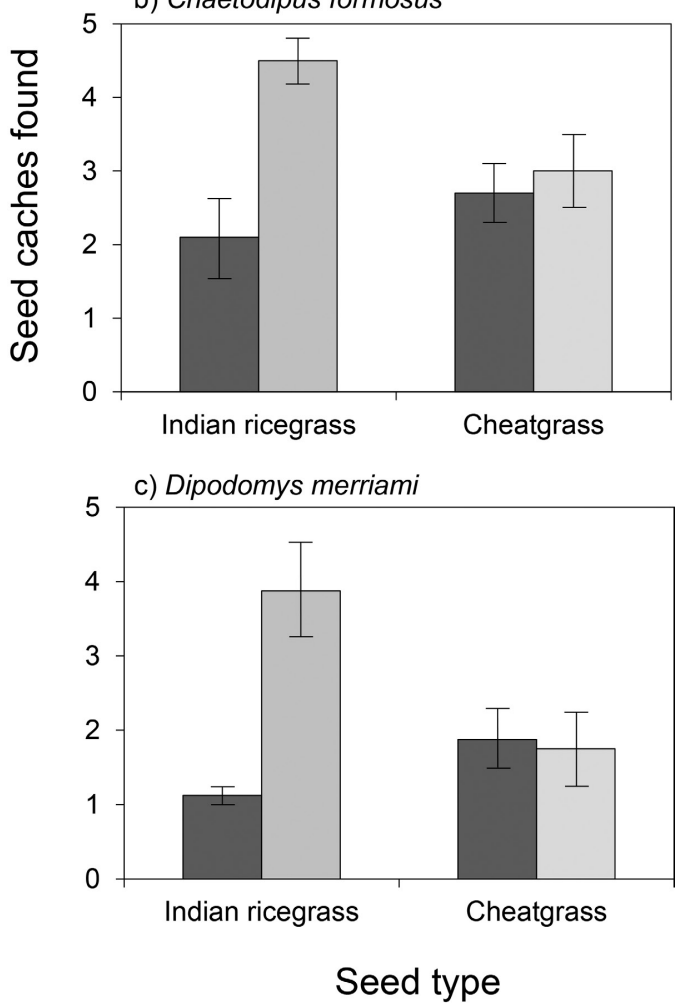

Fig. 4. (a) Mean number of Indian ricegrass and cheatgrass seed caches removed per trial $( \pm \mathrm{SE})$ by 2 heteromyid rodent species in laboratory cache removal experiments for both whole and ground seeds. Cache removal is also shown separately for (b) long-tailed pocket mice (Chaetodipus formosus) and (c) Merriam's kangaroo rats (Dipodomys merriami).

ricegrass seeds over those of cheatgrass. Indirect support for this preference was also provided by laboratory cache removal experiments, as rodents often only partially harvested caches of cheatgrass seeds when they found them but nearly always harvested Indian ricegrass caches completely. 
TABLE 1. Number of laboratory seed cache removal trials $(n=18)$ in which individual heteromyid rodents removed caches of Indian ricegrass and cheatgrass seeds completely and numbers in which caches were partially removed for both whole seeds and ground seeds.

\begin{tabular}{llcc}
\hline & & \multicolumn{2}{c}{$\begin{array}{c}\text { Cache removal } \\
\text { (no. of trials) }\end{array}$} \\
\cline { 3 - 4 } Seed type & $\begin{array}{c}\text { Seed } \\
\text { condition }\end{array}$ & Complete & Partial \\
\hline Indian ricegrass & Whole & 15 & 1 \\
Cheatgrass & Ground & 17 & 1 \\
& Whole & 7 & 14 \\
& Ground & 12 & 8 \\
\hline
\end{tabular}

The prediction that intact cheatgrass seeds would be more easily detected by rodents than Indian ricegrass seeds was supported by field experiment results; despite the strong preference of heteromyid rodents for Indian ricegrass over cheatgrass, rodents removed significantly fewer WI than WC seed caches. We also found support for the predictions that grinding seeds to expose seed embryos would make Indian ricegrass seeds more detectable (as more GI than WI caches were removed by rodents) but that grinding would not necessarily increase the detectability or desirability of cheatgrass seeds (numbers of WC and GC caches removed were similar). Our prediction that grinding seeds would allow rodents to express their preference for Indian ricegrass over cheatgrass by overcoming the lower detectability of intact Indian ricegrass seeds was not supported by field results, as similar numbers of GI and GC caches were removed. However, the latter prediction was strongly supported by results of laboratory cache removal experiments, where significantly more GI than GC caches were removed whether data were combined or tested separately for Merriam's kangaroo rats and long-tailed pocket mice. Furthermore, all of the other predictions discussed above as being supported by field results were also supported by laboratory cache removal results when combined across species; most were also supported for each rodent species tested separately with the exception of WI versus WC cache removal. Given that sample sizes for individual species were relatively small, statistical tests on individual species had lower power for detecting differences.

Foraging rodents detect buried seeds by smelling volatile compounds within seed embryos, and the release of these compounds is enhanced when seeds imbibe water (Jorgensen 2001, Vander Wall 2003, Paulsen et al. 2013). Thus, seed harvest rates by rodents have been found to increase with soil moisture (Johnson and Jorgensen 1981, Vander Wall 1993, 1995, 2000, Taraborelli et al. 2009). Although we did not test effects of soil or seed moisture on cache removal, rain occurred at our field site during 2 of our cache removal trials, and it was only during these 2 trials that rodents removed an equal number of or more intact seed caches of preferred Indian ricegrass (i.e., WI seeds) relative to numbers of intact cheatgrass (WC) caches removed. Vander Wall (1995) tested abilities of 3 scatterhoarding rodent species to locate buried seeds under dry and moist conditions, and although all species showed enhanced ability to locate seeds under wet conditions, only the one heteromyid species tested (Great Basin pocket mouse, Perognathus parvus) was proficient at finding seeds under dry conditions. Jorgensen (2001) measured release of volatile compounds from 3 seed species dispersed by seed-caching rodents, including Indian ricegrass. Seeds of all species released more compounds or released them in greater concentrations when imbibed than when dry, and one of at least 22 compounds identified in Indian ricegrass seeds was released in especially large concentrations when the seeds were imbibed (Jorgensen 2001). Release of such compounds may account for increased harvest rates of moist WI seed caches in our experiment and the greater removal of ground Indian ricegrass (GI) caches relative to WI caches in general.

Indian ricegrass seeds are dispersed by heteromyid rodents, and various lines of evidence suggest that Indian ricegrass and at least one heteromyid species (Merriam's kangaroo rat) enjoy a mutualistic relationship. It is certainly possible that this extends to other heteromyid species as well. The seed resource provided by this preferred food item is an obvious benefit to rodent consumers, but several benefits also accrue to Indian ricegrass plants from their interactions with rodents. McAdoo et al. (1983) found that germination of Indian ricegrass seeds was enhanced by being handled by heteromyids. Longland et al. (2001) tracked radiolabeled Indian ricegrass seeds moved by granivorous rodents and ants at the Hot Springs Mountains, where Merriam's kangaroo rats are the most abundant 
rodent species, and attributed about $95 \%$ of Indian ricegrass seedling recruitment on open control plots to emergence from rodent scatterhoards. In the same experiment, fenced plots in which a single Merriam's kangaroo rat was allowed to eat and cache Indian ricegrass seeds for one night showed the greatest seedling recruitment among numerous experimental treatments. Benefits of seedling emergence from scatterhoards also extend beyond initial recruitment; a previous field experiment showed that survival of Indian ricegrass plants in scatterhoard-like clusters was significantly greater over their first year after establishment than survival of seedlings growing singly (Longland and Dimitri 2016). Vander Wall (2003) and Paulsen et al. (2013) have suggested that seeds of plants which rely on scatterhoarding rodents as dispersers should be selected for reduced olfactory detectability to minimize the probability of seeds being recovered by rodents after they are cached. Results of the studies described here thus add yet another line of support to the mutualistic nature of this rodent-seed interaction. Specifically, our results are consistent with the suggestion that Indian ricegrass has apparently undergone selection for reduced olfactory detectability of its seeds.

It may be possible for land managers to exploit this mutualistic interaction by manipulating or intervening in the seed dispersal services provided by desert rodents. Longland and Ostoja (2013) tested the concept of utilizing preferred, commercial "diversionary" seeds to reduce the rate at which rodents recover Indian ricegrass caches for consumption by using white millet (Pennisetum miliaceum) as a diversionary seed. They documented increased Indian ricegrass seedling recruitment from rodent caches on plots where diversionary seeds were broadcast compared with control plots. However, despite millet being a preferred commercial seed for rodents, it is not consistently ranked higher than Indian ricegrass seeds (Longland and Bateman 1998, Longland and Dimitri 2016). Consequently, Longland and Ostoja (2013) argued that rodent recovery of Indian ricegrass caches for consumption may have been reduced further on diversionary seed plots and resulted in even greater seedling recruitment if a more preferred seed type had been be employed. Following up on this suggestion, Longland and Dimitri (2016) demonstrated that behavioral variation among individual rodents in seed preferences implies that a mixture of different diversionary seed types may be more effective than a single type of diversionary seed. Results of the present study further imply that commercial seeds that are more easily detectable may be good candidates for diversionary seeds due to the tradeoff between seed preferences of desert rodents and seed detectability.

\section{ACKNOWLEDGMents}

We thank A. Murray for field assistance at the Hot Springs Mountains site. All institutional and national guidelines for the care and use of animals in research were followed for this study, and all procedures involving animals were conducted in accordance with University of Nevada, Reno, IACUC approved protocols. This paper is a contribution of the USDA, Agricultural Research Service, Great Basin Rangelands Research Unit, Reno, Nevada.

\section{Literature Cited}

Barga, S.C., AND S.B. VAnder Wall. 2013. Dispersal of an herbaceous perennial, Paeonia brownii, by scatterhoarding rodents. Ecoscience 20:172-181.

Bradley, W.G., AND R.A. Mauer. 1971. Reproduction and food habits of Merriam's kangaroo rat, Dipodomys merriami. Journal of Mammalogy 52:497-507.

CaO, L., Z. Wang, C. Yan, J. Chen, C. Guo, and Z. ZHANG. 2016. Differential foraging preferences on seed size by rodents result in higher dispersal success of medium-sized seeds. Ecology 97:3070-3078.

Fox, B.J. 2011. Review of small mammal trophic structure in drylands: resource availability, use, and disturbance. Journal of Mammalogy 92:1179-1192.

Hay, M.E., and P.J. Fuller. 1981. Seed escape from heteromyid rodents: the importance of microhabitat and seed preference. Ecology 62:1395-1399.

Henderson, C.B. 1990. The influence of seed apparency, nutrient content and chemical defenses on dietary preference in Dipodomys ordii. Oecologia 82:333-341.

Hollander, J.L., S.B. VanderWall, and W.S. Longland. 2012. Olfactory detection of caches containing wildland versus cultivated seeds by granivorous rodents. Western North American Naturalist 72:339-347.

Howard, W.E., AND R.E. Cole. 1967. Olfaction in seed detection by deer mice. Journal of Mammalogy 48: 147-150.

Howard, W.E., R.E. Marsh, and R.E. Cole. 1968. Food detection by deer mice using olfactory rather than visual cues. Animal Behaviour 16:13-17.

JACOBS, L.F. 1992. Memory for cache locations in Merriam’s kangaroo rats. Animal Behaviour 43:585-593.

Johnson, T.K., And C.D. Jorgensen. 1981. Ability of desert rodents to find buried seeds. Journal of Range Management 34:312-314. 
Jorgensen, E.E. 2001. Emission of volatile compounds by seeds under different environmental conditions. American Midland Naturalist 145:419-422.

Kelrick, M.I., J.A. MacMahon, R.R. Parmenter, and D.V. Sisson. 1986. Native seed preferences of shrubsteppe rodents, birds and ants: the relationships of seed attributes and seed use. Oecologia 68:327-337.

Kelt, D.A., J.H. Brown, E.J. Heske, P.A. Marquet, S.R. Morton, J.R.W. Reid, K.A. Rogovin, and G. ShenвRот. 1996. Community structure of desert small mammals: comparisons across four continents. Ecology 77:746-761.

Lobo, N., M. Duong, and J.S. Millar. 2009. Coniferseed preferences of small mammals. Canadian Journal of Zoology 87:773-780.

LOCKARD, R.B., AND J.S. LOCKARD. 1971. Seed preference and buried seed retrieval of Dipodomys deserti. Journal of Mammalogy 52:219-221.

LONGLAND, W.S. 2007. Desert rodents reduce seedling recruitment of Salsola paulsenii. Western North American Naturalist 67:378-383.

LONGLAND, W.S., AND S.L. BATEMAN. 1998. Implications of desert rodent seed preferences for range remediation. Journal of Range Management 51:679-684.

LongLand, W.S., AND L.A. Dimitri. 2016. Can seed caching enhance survival of Indian ricegrass (Achnatherum hymenoides) through intraspecific facilitation? Plant Ecology 217:1523-1532.

LONGLand, W.S., S.H. Jenkins, S.B. Vander Wall, J.A. VEech, AND S. Pyare. 2001. Seedling recruitment in Oryzopsis hymenoides: are desert granivores mutualists or predators? Ecology 82:3131-3148.

LONGLAND, W.S., AND S.M. Ostoja. 2013. Ecosystem services from keystone species: diversionary seeding and seed-caching desert rodents can enhance Indian ricegrass seedling establishment. Restoration Ecology 21:285-291.

Mares, M.A. 1993. Heteromyids and their ecological counterparts: a pandesertic view of rodent ecology and evolution. Pages 652-719 in O.J. Reichman and J.H. Brown, editors, Biology of the Heteromyidae. American Society of Mammalogists, Special Publication $10.719 \mathrm{pp}$.
McAdoo, J.K., C.C. Evans, B.A. Roundy, J.A. Young, AND R.A. Evans. 1983. Influence of heteromyid rodents on Oryzopsis hymenoides germination. Journal of Range Management 36:61-64.

McMurray, M.H., S.H. Jenkins, and W.S. Longland. 1997. Effects of seed density on germination and establishment of a native and an introduced grass species dispersed by granivorous rodents. American Midland Naturalist 138:322-330.

Paulsen, T.R., L. Colville, I. Kranner, M.I. Daws, G. Högstedt, V. VANDViK, and K. Thompson. 2013. Physical dormancy in seeds: a game of hide and seek? New Phytologist 198:496-503.

Pyare, S., and W.S. Longland. 2000. Seedling-aided cache detection by heteromyid rodents. Oecologia 122:66-71.

SAS. 2012. SAS [software]. Version 9.4. SAS Institute, Cary, NC.

Taraborelli, P., N. Borruel, and A. Mangeaud. 2009. Ability of murid rodents to find buried seeds in the Monte Desert. Ethology 115:201-209.

VANDER WALL, S.B. 1993. Seed water content and vulnerability of buried seeds to foraging rodents. American Midland Naturalist 129:272-281.

VANDER WALL, S.B. 1995. Influence of substrate water on ability of rodents to find buried seeds. Journal of Mammalogy 76:851-856.

VANDER WaLL, S.B. 2000. The influence of environmental conditions on cache recovery and cache pilferage by yellow pine chipmunks (Tamias amoenus) and deer mice (Peromyscus maniculatus). Behavioral Ecology 11:544-549.

VANDER WALL, S.B. 2003. How rodents smell buried seeds: a model based on the behavior of pesticides in soil. Journal of Mammalogy 84:1089-1099.

Received 29 September 2017 Revised 11 May 2018 Accepted 8 June 2018

Published online 9 August 2018 